\title{
Design Strategy OF BeKaSi RaIlWAy Station DeVElopMent by SPaCe Circulation Principal
}

\section{Strategi Desain Pengembangan Stasiun Bekasi melalui Penerapan Prinsip Sirkulasi RUANG}

\author{
Muhammad Iqbal Dwi Hendarto ${ }^{1 *}$, Suparno ${ }^{2}$, Samsudi ${ }^{3}$ \\ Program Studi Arsitektur, Fakultas Teknik, Universitas Sebelas Maret ${ }^{1^{*}}$ \\ Hendarto.iqbal@gmail.com \\ Program Studi Arsitektur, Fakultas Teknik, Universitas Sebelas Maret ${ }^{2}$ \\ Program Studi Arsitektur, Fakultas Teknik, Universitas Sebelas Maret ${ }^{3}$
}

\begin{abstract}
Building development is an activity of planning and redesign a building to produce a new physical without altering a particular function or location. The development of railway station made the effort to redesign the railway station while still maintaining the principles and functions of the railwail station building in accordance with standard guide of railway station building. Bekasi City Railway Station is present as a place of activity that gives a big influence for train users in doing activities conveniently through the principles of development and standardization of station. Designing at Railway Station in Bekasi City is needed in realizing the quality of comfort and sustainability of the projection of the number of users within a certain period of time. The method applied in this research, among others, begin with the appointment of number of ideas and phenomena related to railway stations, collection of data and literature that resulted in analysis as a guide in the Development of Railway Station in Bekasi City. From analysis that has been produced through research method, and result of applying The Principle of Development Railway Station in Bekasi City which embodies through the development of space, mass management, building facade.
\end{abstract}

Keywords: Development, Railway Station, Bekasi City.

\section{PENDAhUluaN}

Keberhasilan dalam pembangunan tidak terlepas dari peran bidang transportasi sebagai denyut nadi mobilitas suatu negara. Dewasa ini pembangunan dalam bidang transportasi difokuskan pada perwujudan kualitas sistem transportasi yang handal dan profesional. Salah satu perwujudan tersebut dapat diterapkan dalam transportasi kereta api (Dishubkominfo, 2016).

Kereta api merupakan moda transportasi publik terdiri atas rangkaian lokomotif dan gerbong yang dapat mengangkut penumpang atau barang antar wilayah tertentu yang saling terhubung. Perkeretaapian Nasional memiliki serangkaian visi dan misi yang mampu mewujudkan perkeretaapian yang berdaya saing, berintegrasi dan berteknologi serta saling bersinergi dalam rangka men-jawab tantangan terhadap sistem trans-portasi yang berlangsung di Indonesia. Pemerintah turut serta mendukung dalam pembenahan transportasi kereta api yang sesuai dalam UU nomor 23 tahun 2007 mengenai perkeretaapian. Transportasi kere-ta api memilki peranan penting dalam mendukung pertumbuhan ekonomi pada pengembangan wilayah dan sebagai pemersatu wilayah Negara Kesatuan Republik Indonesia. Hal ini bertujuan dalam rangka mewujudkan Wawasan Nusantara serta memperkukuh Ketahanan Nasional dalam upaya mencapai Tujuan Nasional berdasar- 
kan Undang Dasar Negara Republik Indonesia (Menteri Perhubungan, 2011).

Stasiun kereta api merupakan wadah kegiatan bagi sejumlah pengguna moda kereta api atau barang dalam melakukan kegiatan perpindahan dengan kereta api pada tujuan tertentu. Stasiun kereta api memiliki fungsi utama, antara lain sebagai halte atau pemberhentian bagi kereta api untuk menaikkan atau menurunkan penumpang.

Stasiun Kereta Api Kota Bekasi merupakan stasiun tersibuk ke-4 di Jabodetabek. Stasiun ini melayani kereta api yang berasal dari Jakarta menuju berbagai kota yang ada di $\mathrm{Pu}-$ lau Jawa. Secara umum bangunan dan penataan sirkulasi ruang pada Stasiun Kereta Api Kota Bekasi belum memenuhi standar sirkulasi bangunan fasilitas publik yang ideal. (Firdaus, 2016).

Berdasarkan fenomena tersebut maka dapat dilakukan Pengembangan Stasiun Kereta Api Kota Bekasi Melalui Penerapan Sirkulasi Ruang. Desain pengembangan pada stasiun dapat didefinisikan sebagai proses merancang kembali suatu bangunan fisik stasiun yang telah ada tanpa mengubah fungsi dasar pada bangunan tersebut.

Penerapan Desain Pengembangan Stasiun Kereta Api Kota Bekasi bertujuan dalam mewujudkan desain ideal yang ditinjau dari penataan sirkulasi ruang agar mampu memberikan kenyamanan dan kemudahan bagi pengguna dalam melakukan kegiatan dalam stasiun kereta api.

Dalam desain arsitektur pengembangan stasiun kereta api ini tetap memperhatikan kebutuhan sirkulasi pengguna dan besaran ruang ideal yang sesuai dengan prinsip dasar dan standardisasi pengembangan stasiun kereta api dan kajian prinsip sirkulasi ruang sebagai berikut (DK Ching, 1996).

Prinsip sirkulasi ruang yang diterapkan dalam Pengembangan Stasiun Bekasi memiliki kesesuaian terhadap prinsip sirkulasi wayfinding. Kesesuaian prinsip sirkulasi wayfinding terdapat pada jurnal yang berjudul Stasiun Dukuh Atas Jakarta Sebagai Stasiun Integrasi Moda Transportasi Dengan Pendekatan Sistem Wayfinding. Sistem ini memiliki kesesuaian pada penataan sirkulasi pada Pengembangan Sta- siun Bekasi yang tertuang dalam beberapa aspek berikut (Angga, 2014).

Kemudahan dalam prinsip sirkulasi ruang dapat mencapai semua tempat atau bangunan yang bersifat umum dalam suatu lingkungan.

Kegunaan dalam prinsip sirkulasi ruang dapat dipergunakan pada semua tempat atau bangunan yang bersifat umum dalam suatu lingkungan.

Keselamatan dalam prinsip sirkulasi ruang bangunan yang bersifat umum dalam suatu lingkungan terbangun harus memperhatikan keselamatan bagi pengguna.

Kemandirian dalam prinsip sirkulasi ruang mempergunakan seluruh tempat atau bangunan umum dalam suatu lingkungan dangan tanpa membutuhkan bantuan orang lain.

1.1. Pertimbangan Ukuran Dasar Ruang Sirkulasi Bangunan Stasiun Bekasi (DK Ching, 1996).

Ukuran dasar ruang tiga dimensi yang meliputi panjang, lebar, dan tinggi diperuntukkan sebagai pedoman dalam mendesain Pengembangan Stasiun Bekasi yang ditinjau dari kebutuhan sirkulasi ruang bangunan. Ukuran dasar ruang pada stasiun mengacu pada dua ukuran dasar sebagai berikut.

Ukuran dasar umum meliputi ukuran tubuh manusia, peralatan yang dipergunakan, dan ruang yang dibutuhkan dalam mewadahi pergerakannya, seperti kantor operasional, gudang, ruang petugas dan ukuran dasar khusus meliputi ukuran yang disesuaikan dengan sarana dan prasarana perkeretaapian.

1.2. Bentuk Pola Sirkulasi Ruang Stasiun Bekasi.

Berikut Terdapat beberapa pola sirkulasi ruang yang dapat diterapkan pada Pengembangan Stasiun Bekasi.

Pola sirkulasi direct merupakan pola sirkulasi menuju langsung dan memberikan pilihan tujuan akhir serta akses visual yang diterima oleh pengguna ruang akhir yang dituju.

Pola sirkulasi curvelinear merupakan pola sirkulasi garis linear yang berliku 
Muhammad Iqbal Dwi Hendarto, Suparno, Samsudi, Design Strategy of Bekasi Railway Station ...

halus dan memberikan pilihan akhir. Pola sirkulasi ini memberikan akses visual menuju akhir kurang jelas dan bersifat mengalir.

Pola sirkulasi erratic merupakan pola sirkulasi patah, akses visual menuju akhir kurang jelas dan berpotensi memberikan kejutan ruang.

Pola sirkulasi interupted merupakan pola sirkulasi yang terputus dan pada bagian tertentu akses visual akhir kurang jelas.

Pola sirkulasi looping merupakan pola sirkulasi menuju akhir disamarkan dan memberi kesan apa adanya.

Pola sirkulasi distraction merupakan pola sirkulasi menuju akhir dibiaskan dengan objek lain. Fokus visual mengalir bersama dengan waktu tempuh.

Pola sirkulasi obscure merupakan pola sirkulasi yang bersifat disembunyikan dari jangkauan umum.

Pola sirkulasi diverging merupakan pola sirkulasi yang bercabang dan akses menuju akhir secara fisik dan visual tidak jelas.

Sejumlah pola sirkulasi ruang ini dapat diterapkan dalam Pengembangan Stasiun Bekasi.

1.3. Konfigurasi Sirkulasi Jalan Stasiun Bekasi.

Berikut terdapat beberapa konfigurasi sirkulasi jalan yang dapat diterapkan pada Pengembangan Stasiun Bekasi.

Pola sirkulasi linear merupakan pola sirkulasi dengan pola sederhana dengan pencapaian mudah dan statis terhadap tapak. Jalur ini dapat berbentuk curvelinear atau terpotong dan bersimpangan dengan jalur lain atau bercabang.

Pola sirkulasi radial merupakan pola sirkulasi yang memiliki pusat ruang berkembang berbagai arah dan hubungan antar ruang begitu erat.

Pola sirkulasi grid merupakan pola sirkulasi berkembang berbagai arah dan tidak memiliki pusat ruang dan terdiri atas dua jalur sejajar yang saling berpotongan dan membentuk bujur sangkar.

Pola sirkulasi network merupakan pola sirkulasi berkembang berbagai arah dan dapat menyesuaikan dengan kondisi tapak serta dapat mengarah pada ruang yang dominan sehingga tidak memiliki pusat ruang dan tidak dapat dibentuk suatu pengakhiran.

Pola sirkulasi spiral merupakan pola sirkulasi tunggal yang menerus dari titik pusat dan mengelilingi pusat dengan jarak yang berubah.

Sejumlah pola sirkulasi jalan ini dapat diterapkan dalam Pengembangan Stasiun Bekasi.

1.4. Bentuk Hubungan Antar Ruang Stasiun Bekasi.

Berikut terdapat beberapa konfgurasi hubungan antar ruang yang dapat diterapkan pada Pengembangan Stasiun Bekasi.

Pass by spaces merupakan bentuk hubungan antar ruang sirkulasi yang melewati ruang terpisah jarak dalam menuju ruang lain.

Pass trough spaces merupakan bentuk hubungan antar ruang sirkulasi yang melewati ruang dalam ruang dalam pencapaian menuju ruang.

Terminate in spaces merupakan bentuk hubungan antar ruang sirkulasi yang membawa pengunjung datang langsung menuju tempat tujuan secara frontal.

Sejumlah pola hubungan ruang ini dapat diterapkan dalam Pengembangan Stasiun Bekasi.

1.5. Bentuk Ruang Sirkulasi Stasiun Bekasi.

Bentuk ruang sirkulasi yang terdapat pada bangunan stasiun beragam dan dapat disesuaikan dengan batasannya, seperti keterkaitan dengan hubungan ruang, kualitas skala, proporsi, pencahayaan hingga pemandangan. Berikut terdapat beberapa bentuk ruang sirkulasi yang dapat diterapkan pada Pengembangan Stasiun Bekasi.

Enclosed merupakan bentuk ruang sirkulasi yang bersifat tertutup bagi 
pengguna. Penerapan ruang tertutup dimungkinkan dalam pemanfaatan kebutuhan privasi tertentu oleh pengguna. Penerapan enclosed dapat diterapkan pada bangunan kantor dan privasi rapat.

Open on one side merupakan bentuk ruang sirkulasi yang mengoptimalkan sirkulasi cahaya dan udara masuk menuju area pengguna. Bentuk ini sangat baik digunakan pada bangunan semi terbuka dan tidak memilki tingkat privasi tinggi.

Open on both side merupakan bentuk ruang sirkulasi yang memiliki banyak bukaan pada setiap sisi bangunan. Bentuk sirkulasi ini sangat baik digunakan pada bangunan dengan privasi rendah sehingga dapat menghemat material bangunan. Sirkulasi ini sangat baik untuk sirkulasi pencahayaan dan udara.

Sejumlah bentuk ruang ini dapat diterapkan dalam Pengembangan Stasiun Bekasi.

\section{METODE}

Metode yang diterapkan dalam dalam penelitian ini, antara lain menggunakan metode prinsip sirkulasi ruang pengembangan stasiun. Metode ini bersumber dari Standardisasi Bangunan Perkeretaapian Indonesia 2012 dan teori penerapan strategi desain sirkulasi ruang (DK Ching 1996).

Beberapa sistematika metode penelitian yang diterapkan dalam penelitian ini, antara lain.

2.1. Mencari permasalahan, fenomena, isu yang ditentukan melalui kajian literatur perkeretaapian, artikel (koran, majalah) hingga studi lapangan (objek stasiun kereta api). Fenomena terhadap tingginya kepeminatan pengguna kereta api dalam sebuah stasiun yang tidak sebanding dengan kapasitas ruang bangunan dan penyelesaiannya melalui prinsip sirkulasi ruang sebagai stategi desain.

2.2. Mengumpulkan sejumlah data terkait dihimpun dari artikel, literatur dan studi lapangan permasalahan pengguna moda transportasi kereta api dan menyesuaikan terhadap teori arsitektur terkait prinsip sirkulasi ruang (DK Ching 1996).
2.3. Melakukan analisis pada prinsip srikulasi pengembangan stasiun melalui penataan ruang dan besaran ruang. Hasil analisis berupa rumusan konsep dan transformasi desain yang dapat menjadi acuan dalam Pengembangan Stasiun Kereta Api Kota Bekasi.

Terdapat Sejumlah Strategi desain yang diterapkan dalam Pengembangan Stasiun Kereta Api Bekasi Melalui Penerapan Prinsip Sirkulasi Ruang.

Penataan kembali bangunan eksisting stasiun dan melakukan serangkaian perubahan sejumlah fungsi dan sirkulasi ruang, seperti penempatan ruang pengelola pada setiap zonasi bangunan stasiun, penyesuaian dimensi terhadap ukuran peron yang ideal hingga penataan sirkulasi masuk dan keluar stasiun. Penerapan konsep tata massa bangunan baru di adaptasi dari beberapa layout bangunan lama stasiun. Penataan kembali layout ruang dan perbaikan arus sirkulasi pengguna yang akan dilebur dalam sejumlah zonasi bangunan. Sejumlah massa eksisting dan utilitas pada bangunan Stasiun Kereta Api Bekasi tetap dipertahankan. Perencanaan kembali fasilitas utama dan penunjang dalam wadah kegiatan Stasiun Kereta Api Kota Bekasi yang bertujuan dalam meningkatkan kualitas yang ditinjau dari sisi kenyamanan, keamanan, dan keselamatan bagi pengguna yang menggunakan moda kereta api sebagai moda transportasi utama dalam mobilitas sehari-hari.

\section{HASIL DAN PEMBAHASAN}

Pengembangan Stasiun Kereta Api Kota Bekasi merupakan pembangunan kembali bangunan stasiun dengan merencanakan kembali sejumlah fungsi dan fasilitas dalam rangka peningkatan kualitas pelayanan terhadap pengguna transportasi kereta api.

Strategi pengembangan stasiun melalui prinsip sirkulasi ruang yang direncanakan meliputi penataan tata massa dan sirkulasi ruang, fungsi ruang kegiatan pengguna kereta api, penataan sirkulasi pejalan kaki hingga penataan lahan parkir. Pengembangan Stasiun Kereta Api Kota Bekasi yang direncanakan merupakan wadah kegiatan dengan fasilitas 
pelayanan yang telah dikelola oleh PT. Kereta Api Persero yang mengedepankan visi dan misi perusahaan.

Strategi Desain Pengembangan Stasiun Bekasi Melalui Prinsip Sirkulasi Ruang dapat dilakukan dengan memerhatikan kemudahan, kegunaan, keselamatan dan kemandirian dapat dijelaskan dalam beberapa poin sebagai berikut.

\subsection{Strategi Desain Pengembangan Tata Massa Melalui Prinsip Sirkulasi Rua- ng.}

Strategi ini menjelaskan perubahan yang terjadi pada eksisting dan pengembangan yang terjadi pada tata massa bangunan beserta fungsinya.

Eksisting bangunan stasiun ini memiliki dua massa bangunan yang saling berhadapan satu sama lain (lihat Gambar 1.). Massa bangunan ini diapit oleh empat jalur kereta api pada kondisi eksisting. Massa bangunan ini memuat fungsi operasional dan perkan-toran dalam satu atap massa. Fungsi massa di sisi utara terdapat pelayanan operasional baik kereta jarak jauh dan KRL, perkantoran kepala stasiun dan staff hingga mushalla. Sementara fungsi massa bangunan pada sisi selatan terdapat fungsi pelayanan opersional KRL dan perkantoran KRL serta ruang tung-gu. Bentuk tata massa bangunan eksisting ini merupakan bentuk massa persegi panjang dengan layout ruang sederhana.

Pada pengembangan stasiun ini memiliki satu massa penghubung yang terletak di atas dua massa eksisting (lihat Gambar 2.). Massa penguhubung ini berfungsi sebagai fungsi kegiatan operasional pelayanan secara maksimal. Sementara fungsi massa eksisting dipergunakan sebagai massa kantor dan pelayanan administrasi, kru kereta api, hingga utilitas. Massa bangunan eksisting ini mengalami sedikit permainan massa pada sisi utara untuk menghilangkan kesan kaku dan formal dari massa bangunan eksisting. Bentuk tata massa bangunan pengembangan memiliki bentuk massa persegi yang terdapat di atas massa eksisting dalam konteks ini pengembangan bersifat fungsional dan tidak ada penambahan elemen kompleks dan cenderung sederhana.

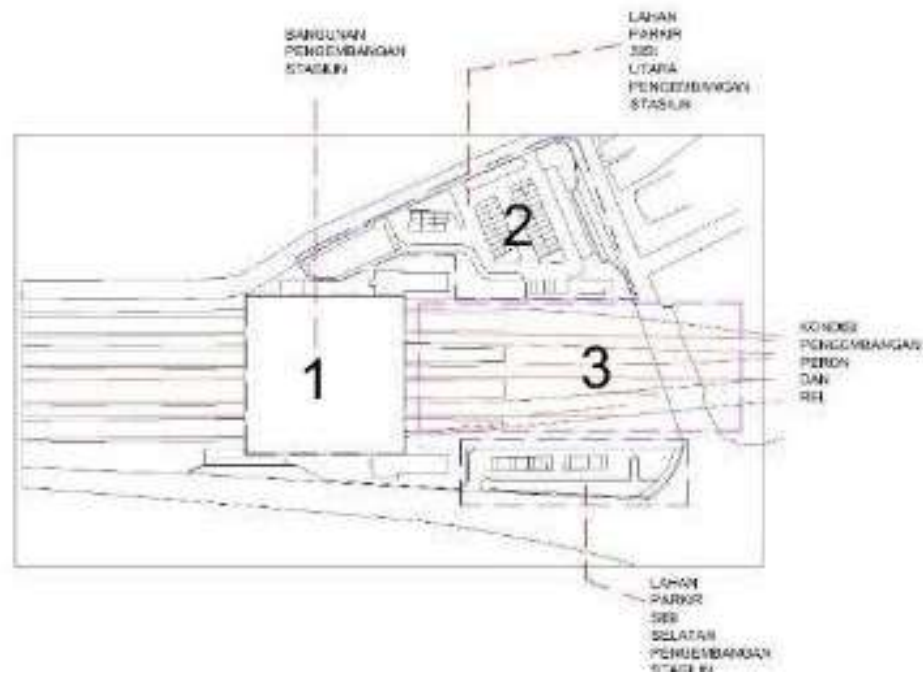

Gambar 1. Kondisi Asli Tata Massa Bangunan Stasiun Bekasi.

Sumber: Dinas Kereta Api Indonesia.

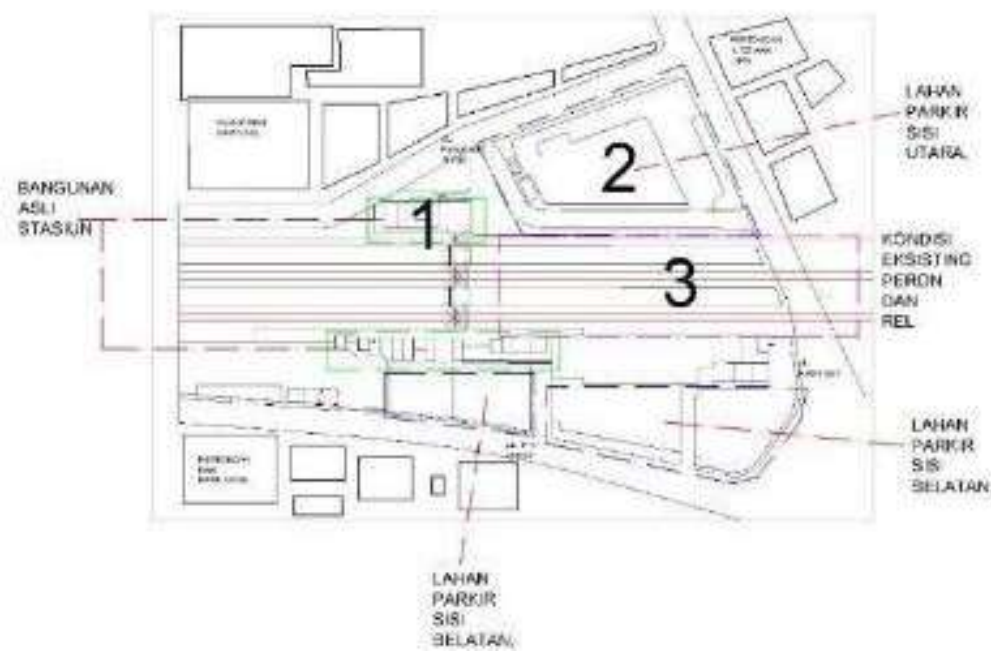

Gambar 2. Kondisi Pengembangan Tata Massa Stasiun Bekasi.

Prinsip Sirkulasi Ruang Tata Massa Pengembangan Stasiun Bekasi.

Sirkulasi eksisting tata massa bangunan stasiun ini menerapkan pola sirkulasi linear karena tata massa eksisting ini menghubungkan massa pada sisi selatan dan utara.

Pada pengembangan sirkulasi tata massa pengembangan ini tetap menerapkan pola sirkulasi linear tata massa bangunan ini mengubungan satu ruang menuju ruang lain satu arah dan sebaliknya.

3.2. Strategi Desain Pengembangan Fungsi Ruang Melalui Prinsip Sirkulasi Ru- 
ang pada Pengembangan Stasiun Bekasi.

Strategi ini menjelaskan perubahan yang terjadi pada eksisting dan pengembangan terhadap ruang yang terdapat pada bangunan Stasiun Bekasi.

Eksisting fungsi ruang yang terdapat pada stasiun ini tetap dipertahankan sesuai kondisi bangunan awal. Namun ada beberapa penambahan fasilitas guna meningkatkan pelayanan terhadap pengguna kereta api. Setiap ruang pada bangunan stasiun memiliki fungsi tertentu yang sesuai dengan kegiatan dan fasilitas pelayanan terkait. Secara umum pembagian ruang pada stasiun berdasarkan fungsinya dikelompokkan menjadi dua, antara lain (lihat Lampiran 1.).

a. Ruang kegiatan pokok merupakan ruang yang diperuntukkan bagi kegiatan yang berkaitan langsung dengan penyelenggaraan jasa perkeretaapian. Ruang kegiatan pokok terbagi kedalam dua bagian utama, antara lain ruang kepala stasiun, ruang wakil kepala stasiun, ruang PPKA, ruang PAP, ruang keuangan, ruang serbaguna, ruang peralatan, ruang UPT kru $\mathrm{KA}$, ruang istirahat kru KA, ruang petugas keamanan, dan ruang petugas kebersihan.

b. Ruang pelayanan publik, antara lain ruang hall, ruang loket, ruang pelayanan informasi, ruang tunggu VIP, ruang tunggu umum, ruang peron, ruang pelayanan kesehatan, ruang lavatory umum, ruang mushalla, ruang merokok, dan ruang ibu menyusui.

c. Ruang kegiatan penunjang dan pelayanan khusus merupakan ruang yang diperuntukkan bagi kegiatan komersial ruang ini meliputi ruang pertokoan, ruang restoran, ruang parkir kendaraan, dan ruang ATM.

Fungsi ruang yang terdapat pada stasiun belum sepenuhnya diterapkan secara maksimal. Hal ini disebabkan oleh terbatasnya kondisi tata massa eksisting yang memungkinkan adanya pengembangan terhadap massa bangunan stasiun secara vertikal. Sejumlah ruang seperti ruang tunggu VIP, ruang merokok, ruang menyusui, hingga toko belum tersedia pada Stasiun Bekasi ini.
Pada pengembangan fungsi ruang stasiun telah diterapkan secara maksimal. Hal ini telah mengacu pada pedoman standardisasi bangunan perkeretaapian dan standar sirkulasi ruang. Penambahan fungsi ruang penunjang dapat memungkinkan pemanfaatan fasilitas ruang secara maksimal oleh pengguna kereta api dalam melakukan mobilitasnya sehari hari. Fungsi ruang yang di tambahkan (lihat Lampiran 2.) dalam Strategi Desain Pengembangan Stasiun Bekasi Melalui Prinsip Sirkulasi Ruang, antara lain.

d. Gedung kegiatan pokok, meliputi perkantoran operasional stasiun, loket tiket, ruang tunggu dan peron, ruang informasi, ruang fasilitas keamanan, ruang fasilitas kesehatan, lahan parkir kendaraan pengguna, hall/ lobby utama, dan lahan parkir kendaraan staff.

e. Gedung kegiatan penunjang, seperti pertokoan dan minimarket.

Prinsip Sirkulasi Ruang Terhadap Sejumlah Ruang Pada Pengembangan Stasiun Bekasi.

Eksisting sirkulasi ruang yang diberikan pada setiap ruang bangunan eksisting menerapkan bentuk antar ruang pass by spaces. Hal ini terlihat dari tata massa eksisting yang memanjang dan terdapat selasar di sisi massa bangunan. Pada bagian ruang kantor dan pelayanan memliki bentuk ruang sirkulasi yang berbentuk enclosed karena ruang eksisting dari bangunan ini bersifat tertutup. Sementara itu pada bagian peron menerapkan bentuk sirkulasi open on both side (lihat Lampiran 3.) karena memiliki privasi rendah.

Pengembangan sirkulasi ruang yang diberikan dalam bangunan Stasiun Bekasi menerapkan bentuk antar ruang pass by space (lihat Lampiran 4.).

Terlihat dari sirkulasi tata ruang yang terdapat selasar pada setiap sisi ruang. Pada bagian ruang kantor dan utilitas memiliki bentuk ruang sirkulasi yang berbentuk enclosed karena memiliki tingkat privasi yang tertutup. Sementara pada bagian pelayanan dan hall menggunakan bentuk open on one side. Selanjutnya pada bagian peron menggunakan bentuk ruang sirkulasi open on both side sebab memiliki privasi rendah dan dapat 
memaksimalkan penghawaan dan pencahayaan ruang stasiun.

3.3. Strategi Desain Pengembangan Jalur Pejalan Kaki Melalui Prinsip Sirkulasi Ruang.

Strategi ini menjelaskan perubahan yang terjadi pada eksisting dan pengembangan terhadap jalur pejalan kaki yang terdapat pada lingkungan Stasiun Bekasi.

Eksisting jalur pejalan kaki yang terdapat pada lingkungan stasiun sudah tidak berfungsi baik. Jalur pejalan kaki difungsikan sebagai lapak jual beli dan ruang tunggu bagi penyedia jasa transportasi roda dua. Hal tersebut membuat jalur pejalan kaki yang terdapat pada lingkungan stasiun sudah seharusnya dilakukan penataan dalam rangka kelancaran sirkulasi bagi pengguna menuju stasiun.

Pada pengembangan jalur pejalan kaki sudah disediakan dan jalur pejalan kaki ini memiliki keterhubungan dan sirkulasi masuk menuju stasiun dan lingkungan sekitar stasiun. Hal ini membuat sejumlah lapak jual beli dipindahkan pada massa bangunan pengembangan yang sudah disediakan pada blok yang ditentukan.

Prinsip Sirkulasi Ruang Terhadap Jalur Pejalan Kaki Pada Pengembangan Stasiun Bekasi.

Eksisting jalur pejalan kaki yang terdapat pada stasiun hanya diperuntukkan bagi pejalan kaki dengan satu lajur hanya memuat satu orang dengan ukuran $80 \mathrm{~cm}$. Konfigurasi jalan terhadap sirkulasi pejalan kaki Stasiun Bekasi menggunakan sirkulasi linear (lihat Gambar 3.). Bentuk hubungan sirkulasi antar ruang pada pejalan kaki ini membentuk pola pass by spaces karena sifatnya melawati selasar pada sisi lingkungan stasiun.

Pengembangan jalur pejalan kaki yang terdapat pada stasiun ini peruntukkan bagi pejalan kaki berukuran 4 meter. Bentuk hubungan sirkulasi antar ruang pada pejalan kaki ini membentuk pola pass by spaces (lihat Gambar 4.) karena sifatnya melewati selasar sisi bangunan stasiun.

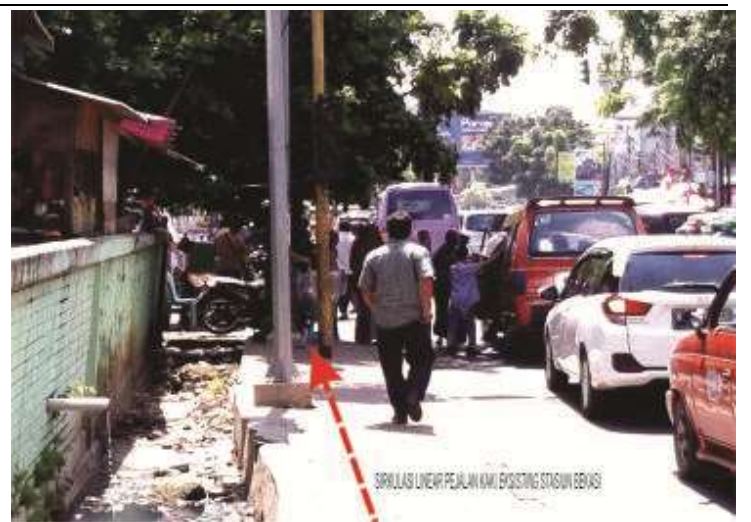

Gambar 3. Kondisi Eksisting Jalur

Pejalan Kaki Stasiun Bekasi yang Sesuai Dengan Prinsip Sirkulasi Linear.

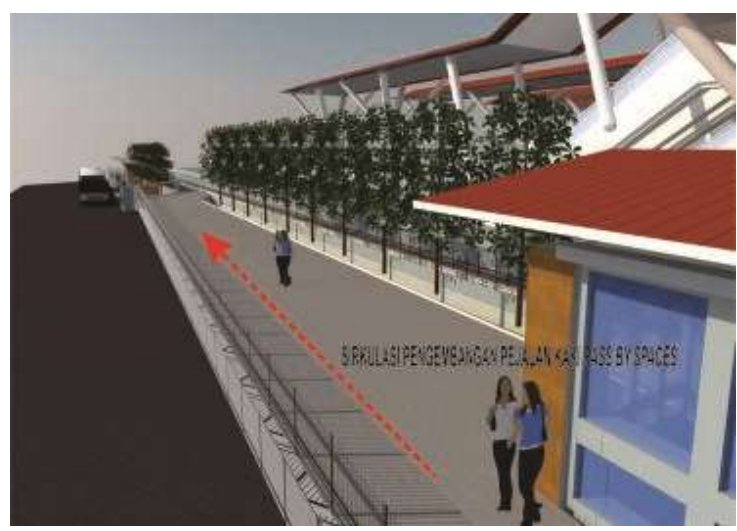

Gambar 4. Kondisi Pengembangan Jalur Pejalan Kaki Stasiun Bekasi yang Sesuai Dengan Prinsip Sirkulasi Pass By Spaces.

3.4. Strategi Desain Pengembangan Penataan Parkir Melalui Prinsip Sirkulasi Ruang.

Strategi ini menjelaskan perubahan yang terjadi pada eksisting dan pengembangan terhadap penataan ruang parkir yang terdapat pada lingkungan Stasiun Bekasi.

Eksisting parkir yang terdapat pada lingkungan stasiun terdapat pada dua sisi, antara lain sisi utara dan selatan. Pada sisi selatan difokuskan hanya untuk kendaraan bermotor, sementara pada sisi utara difokuskan bagi pengendara mobil dan motor pengunjung serta kendaraan staff yang memuat lahan parkir. Dalam kondisi eksisting lahan parkir ini memuat sirkulasi grid (lihat Gambar 5.).

Pengembangan lahan parkir Stasiun Bekasi tetap terdapat pada dua sisi, antara lain sisi utara dan selatan. Namun dalam pengembangan ini lahan parkir pada sisi utara difokuskan pada lahan parkir kendaraan mobil dan motor, sementara pada sisi selatan la- 


\section{han parkir difokuskan pada kendaraan mobil} dan motor untuk pemberhentian sementara.

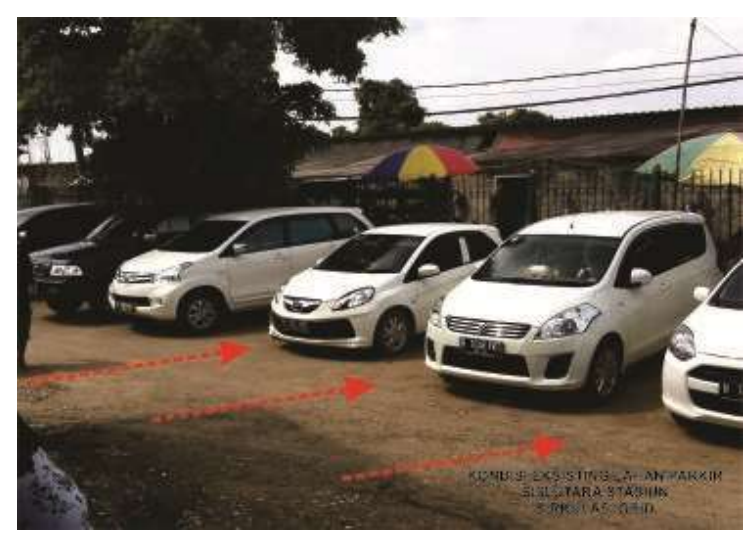

Gambar 5. Kondisi Eksistng Lahan Parkir Stasiun Bekasi dengan Sirkulasi Grid. Sumber: Dinas Kereta Api Indonesia.

Prinsip Sirkulasi Ruang Terhadap Penataan Parkir pada Pengembangan Stasiun Bekasi.

Eksisting sirkulasi parkir yang terdapat pada stasiun ini memuat sirkulasi grid. Sirkulasi ini memperlihatkan ketersediaan terhadap lahan parkir. Hal ini bertujuan dapat memaksimalkan lahan dan kapasitas parkir Stasiun Bekasi. Pada pengembangan sirkulasi parkir mempertahankan bentuk eksisting sirkulasi lahan parkir dan memuat sirkulasi grid (lihat Lampiran 5).

Berdasarkan kesesuaian terhadap lokasi pada pengembangan stasiun, maka lokasi tetap pada Jalan Ir. H. Juanda, Kota Bekasi (lihat Lampiran 6.). Tapak bangunan stasiun ini menghadap sisi selatan. Lokasi tapak ini diperuntukkan sebagai fungsi pelayanan kegiatan moda transportasi kereta api di Kota Bekasi.

Adapun batas tapak.

Utara : Jalan warga, permukiman Kelurahan Marga Jaya, Bekasi Utara.

Selatan : Jalan Ir. H. Juanda, Jalan Utama Kota Bekasi.

Barat : Lokasi Rel KA Langsir dan batu bara (non-aktif).

Timur : Jalan Perjuangan, Jalan utama Bekasi Utara.

Tata Guna Lahan.

$\begin{array}{ll}\text { Fungsi } & : \text { Wadah transportasi } \\ \text { KDB } & : 50 \%\end{array}$

$\begin{array}{ll}\text { KLB } & : 1,5 \\ \text { GSB } & : 20 \text { meter } \\ \text { Tinggi Bangunan } & : 2 \text { lantai } \\ \text { Luas Tapak } & : 27.000 \mathrm{~m} 2 \\ \begin{array}{l}\text { Potensi } \\ \text { pusat Kota } \\ \text { kebudayaan. }\end{array} & : \text { Tapak strategis titik } \\ \end{array}$

\section{KESIMPULAN}

Stasiun Kereta Api Kota Bekasi merupakan wadah kegiatan bagi pengguna moda transportasi kereta api dalam melakukan perpindahan dengan memanfaatkan sejumlah fasilitas pendukung yang terdapat di dalam stasiun kereta api. Stasiun Kereta Api Kota Bekasi sangat berperan dalam keberlangsungan dan menjadi kebanggaan bagi warga Kota Bekasi sebagai wadah kegiatan dalam transportasi perkeretaapian.

Dalam desain pengembangan ini dilakukan penataan kembali bangunan eksisting stasiun dengan cara melakukan serangkaian perubahan sejumlah fungsi ruang, seperti penempatan ruang pengelola pada setiap zonasi, penambahan dimensi ukuran terhadap ukuran peron yang ideal hingga penataan sirkulasi masuk dan keluar stasiun.

Penerapan konsep tata massa bangunan baru diadaptasi dari beberapa layout bangunan lama, penataan kembali layout ruang dan perbaikan arus sirkulasi pengguna yang akan dilebur dalam sejumlah zonasi bangunan stasiun.

Perencanaan kembali sejumlah fasilitas utama dan penunjang dalam wadah kegiatan Stasiun Kereta Api Kota Bekasi yang bertujuan dalam meningkatkan kualitas kenyamanan, keamanan, dan keselamatan bagi pengguna yang menggunakan moda kereta api sebagai moda transportasi utama seharihari.

\section{REFERENSI}

Caesar, Maulana A. (2014). Stasiun Dukuh Atas Jakarta Sebagai Stasiun Integrasi Antar Moda Transportasi Massal Dengan Pendektanan Sistem Wayfinding, Arsitektura No.1 Vol 12. Surakarta.

Dishubkominfo. (2016). Sistem Transportasi Nasional[online]bersumberhttp;/dbtranspo 
rtasi.dishubkominfo.kalbarprv.go.id/.[diaks es pada 28 Oktober 2016].

DK.Ching,Francis. (1996). Form Space and Order sirkulasi ruang halaman 278, Erlangga, Jakarta.

Firdaus, N. (2016). Stasiun Bekasi Butuh Perluasan Parkir [Online] bersumber. http://megapolitan.antaranews.com/.[diakse s pada 28 Oktober 2016].

Kereta Api Indonesia. (2012) Pedoman Standardisasi Bangunan Kereta Api, PT. Kereta Api Indonesia, Bandung.

Menteri Perhubungan. (2011). Undang-undang nomor 43 tahun 2011 rencana induk perkeretaapian nasional.Jakarta. 


\section{LAMPIRAN}

Lampiran 1. Kondisi Eksisting Denah Stasiun Bekasi yang Memiliki Fasilitas Ruang Secara Umum Pada Stasiun.

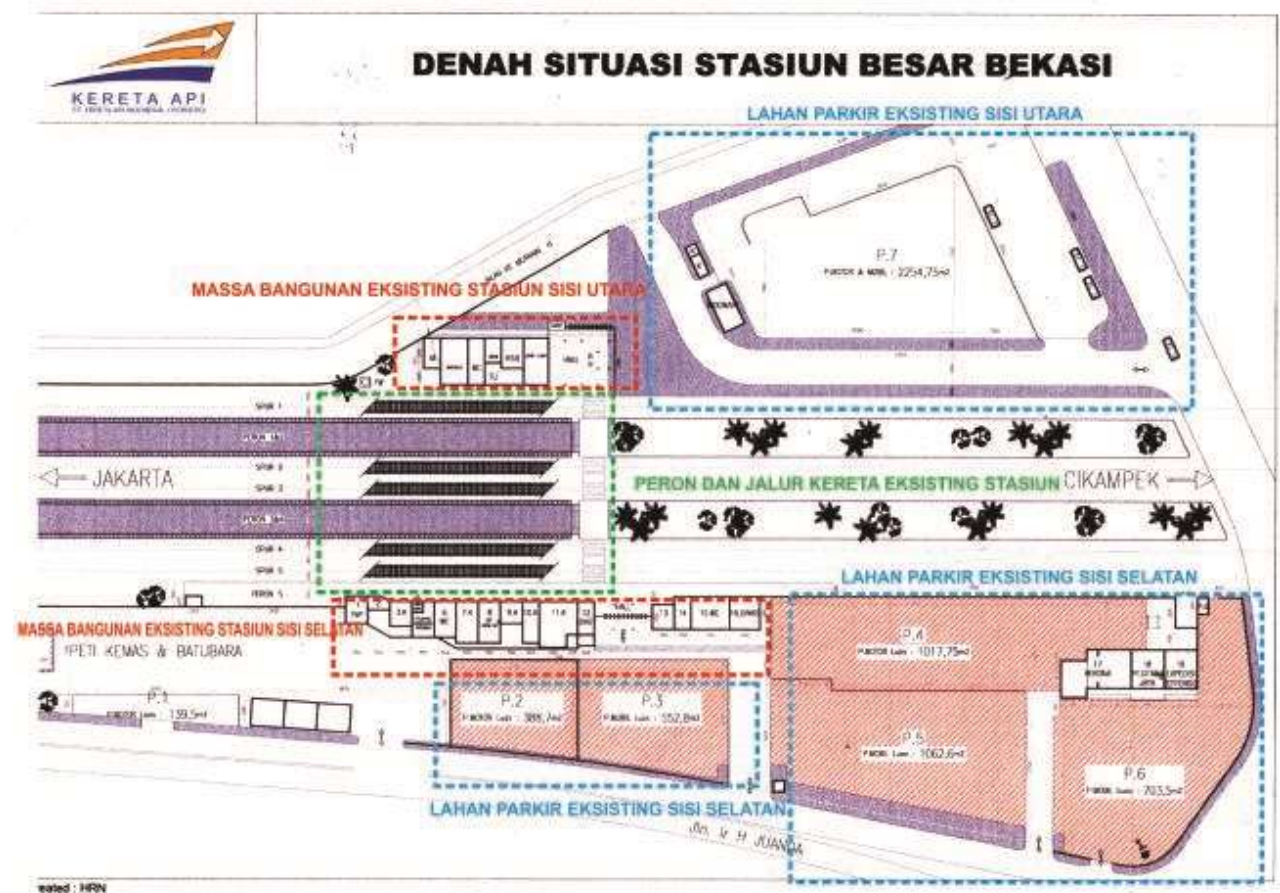

Lampiran 2. Kondisi Pengembangan Denah Stasiun Bekasi yang Memiliki Sejumlah Fasilitas Ruang Pada Stasiun.

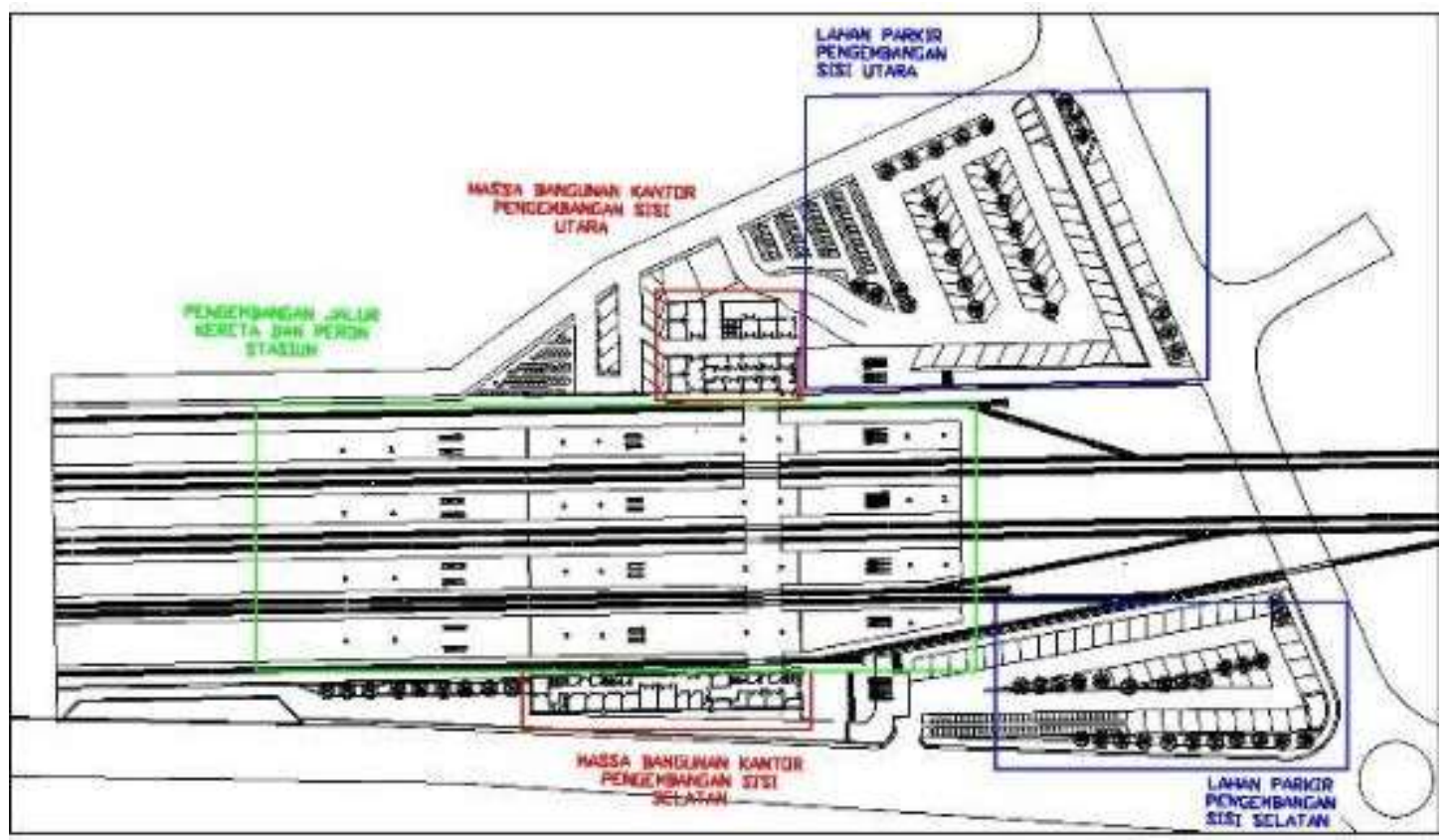


Muhammad Iqbal Dwi Hendarto, Suparno, Samsudi, Design Strategy of Bekasi Railway Station ...

LAMPIRAN

Lampiran 3. Kondisi Pengembangan Denah Lantai Satu Stasiun Dengan Prinsip Sirkulasi Open On Both Side.

SIRKLLASI

PENGEMBANGAN

BCTH LN STDE

SIRKULASI

PENGEMBANGAN

ODTH UN SIDE

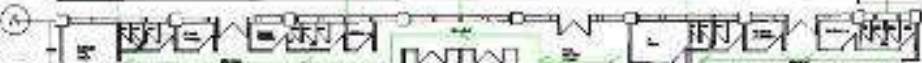

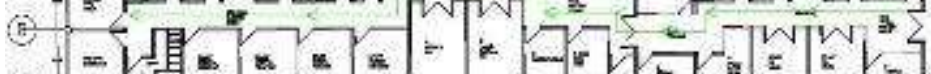

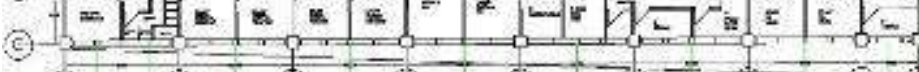

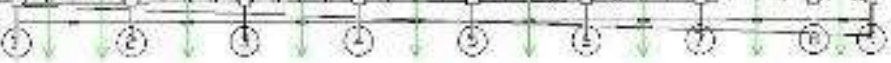

QDENAH KORTCR LT I SELPTAN

sxas 150

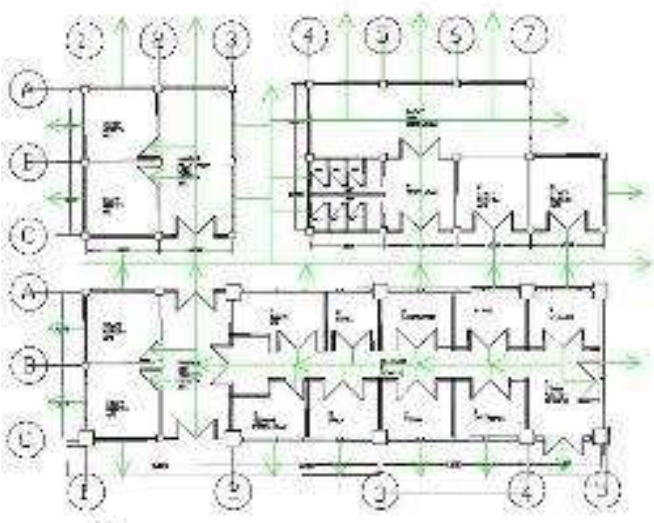

BE VI:A KMITLR LTARO Sk. 4 tका

Lampiran 4. Kondisi Pengembangan Denah Lantai Dua Stasiun Bekasi Dengan Prinsip Sirkulasi Pass By Spaces.

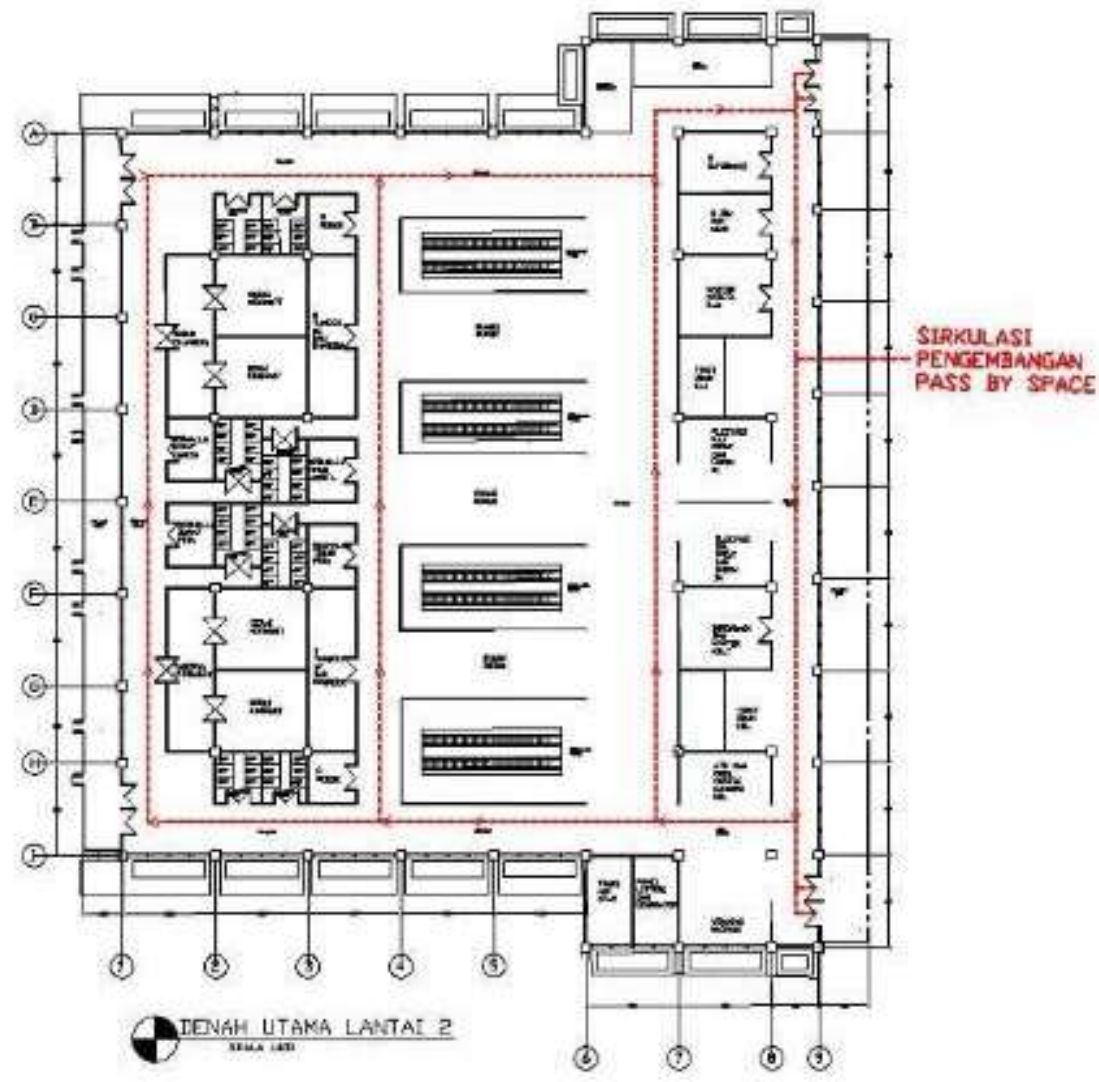


Arsitektura, Vol. 16, No.2, Oktober 2018: 219-230

\section{LAMPIRAN}

Lampiran 5. Kondisi Pengembangan Lahan Parkir Stasiun Bekasi Dengan Menerapkan Prinsip Sirkulasi Grid.

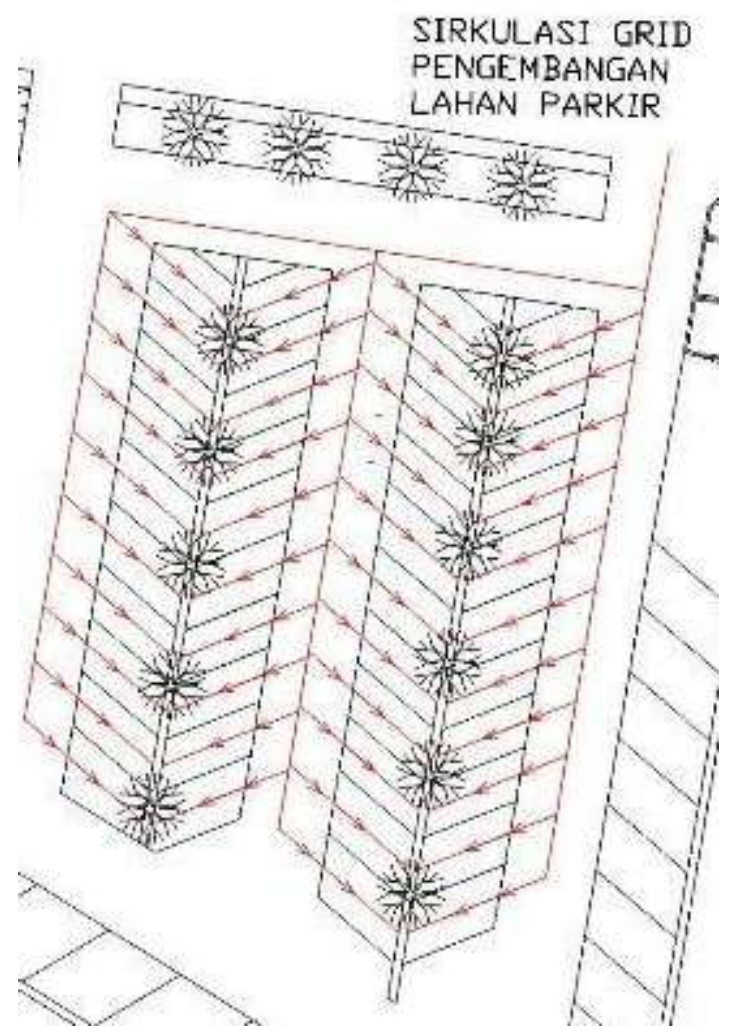

Lampiran 6. Kondisi Tapak Pengembangan Stasiun Kereta Api dengan Prinsip Sirkulasi Ruang.

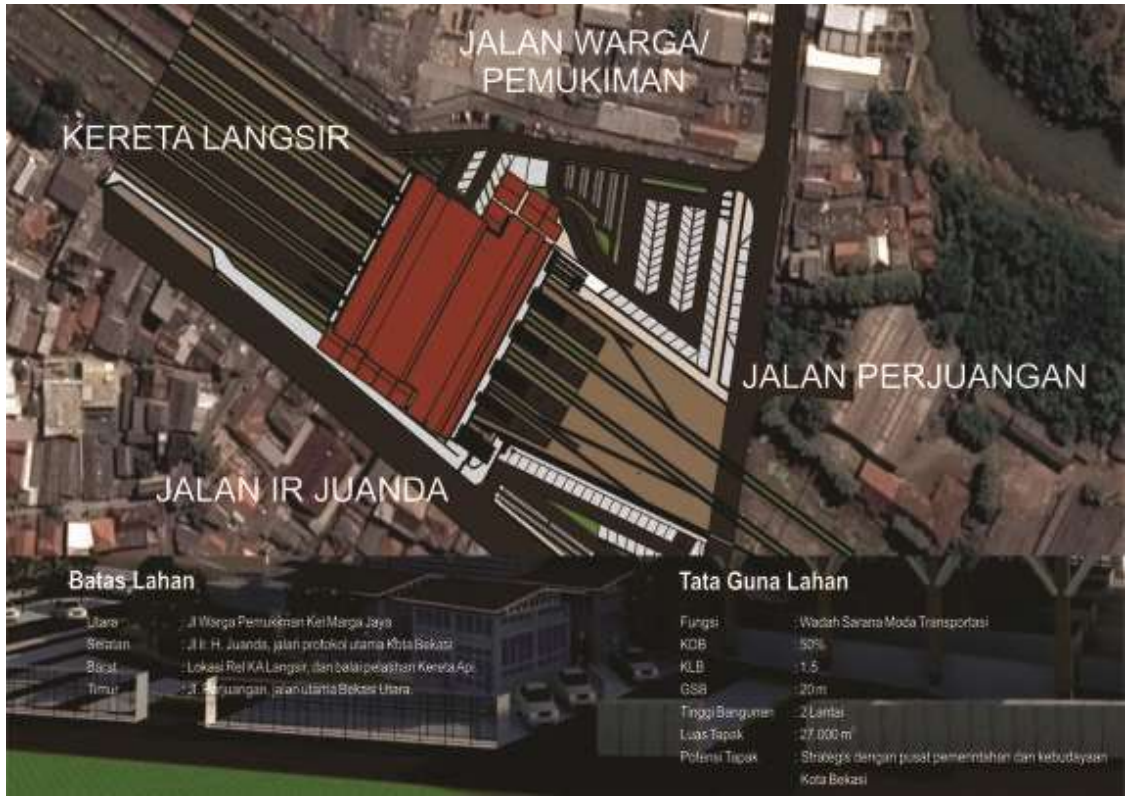

